the complete penetration of an object by steam heat for more than five minutes is sufficient for its thorough disinfection.

The apparatus wbich I have designed and wbich has been admirably constructed by Messrs. Bailey Brothers, of Epworth and Bawtry, will be easily understood by a glance at the accompanying illustration. Circular in shape and

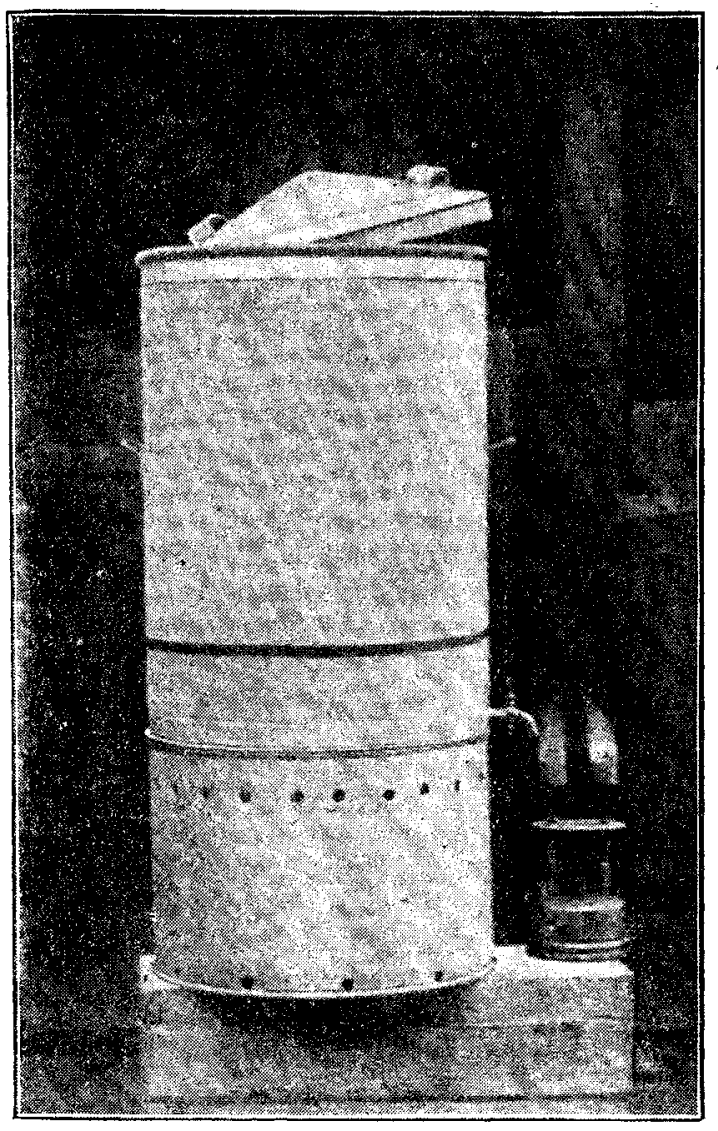

made of galvanised iron it measures $4 \mathrm{ft}$. in height, with a diameter of 21 in. A portion of the height ( $2 \mathrm{ft} .10 \mathrm{in}$.) is taken up by the chamber and the lid, which are separated from the pedestal immediately below the level of the tap. Six inches above the tap will be seen a black line which corresponds with a removeable perforated false bottom in the interior. Above the false bottom is the disinfecting chamber; the space below is the boiler. The pedestal is $14 \mathrm{in}$. high. The chamber and the lid are covered with felt, and the lid is perforated at the top to allow of the slinging of a thermometer and the escape of steam, and by means of a simple contrivance the junction of the lid and cbamber is made almost completely steam-tight. The heating power within the circle of the pedestal is derived from an " intensive oil furnace," which throws out an immense heat by means of volatilised petroleum. 'This heating arrangement (for the suggestion of which I have to thank Mr. Alfred Bailey) does away with all difficulty connected with the construction of a light, portable disinfecting apparatus. The whole thing, lamp and all, weighs only $54 \mathrm{lb}$. and costs less than a penny to work for one hour; and even when it is full of blankets and clothes the temperature in the middle of them reaches $100^{\circ} \mathrm{C}$. in half an hour from the time of the water in the boiler being cold. I find that an inch and a half of water in the boiler is more than enough for one disinfection.

When the clothes are removed they ought to be immediately shaken in the open air and then freely exposed on a clothes line for half an hour, at the end of which time they will be found to be practically dry. This apparatus, which has been adopted by my sanitary authority, can be carried about in a trap with perfect ease, and can of course be enlarged to any extent on the same model with a corresponding increase of heating power.

Epworth, Doncas ter.

Builth Cottage Hospital. - The new cottage hospital for Builth was opened on Nov. 3rd. The chairman of the builoing committee stated that the late $\mathrm{Mr}$. John Davies, of Wyeside, had bequeathed $£ 6000$ to build and endow the institution, and added that the committee had expended $£ 2600$ upon the hospital, leaving an endowment of over $£ 3000$, but as this was insufficient they appealed for further funds from the inhabitants.

\section{ON POOR-LAW MEDICAL ECONOMICS. ${ }^{1}$}

BY ThOMAS M. DOLAN, M.D., F.R C.S. Edin., J.P:, MEDICAL OFFICER, 8T. LUKK'S HOSPITAL, HALIFAX.

THE title of my paper will, I hope, be justified when I have read the paper. It was suggested that I should write on Poor-law Medical Adminisratiton; but the medical officer is only an adviser, and I have always steered clear of attempting to usurp the position which belongs to you. You will therefore understand that I confine myself still to the same rôls; that I simply throw out suggestions or ideas (or shall I say ideals?) on Poor-law medical requirements, while dwelling strongly on general principles which strike me, as a medical man, as applicable to the great problems you have to deal with. I draw, too, on my experience-a ripe one, extending to nearly thirty years in the service.

You all recognise the grave responsibilities and serions duties which fall upon you as guardians in the matter of medical relief-duties and responsibilities which are increasing rather than diminishing. You are discharging in this country duties which in my travels in Germany, France, Austria, and Russia I find are undertaken by the municipalities or corporations. You have medical charge of infants and children, you have hospitals for the sick poor suffering from acute diseases, whilst you also make provision for the incurable, the infirm, the dying, and the aged. And you have also lying-in wards, so that your medical field is all-embracing. You have a large staff of medical officers, nurses, as well as other necessary officials, and your expenses are great, so that economics are worth consideration. It is an old electioneering cry, "Economy with efficiency." Nothing can be truer when applied even to medical relief. For the effective relief of sickness it appears to me that the only true economy is to provide adequate medical aid. If you accept this principle, as it has been accepted by the Bradford guardians, by the Leeds guardians, by the Halifar guardians, my task will be simpler. It is because you believe that the sick poor for whom you are responsible are entitled to fresh air, good baths, skilled nursing, sufficient and unfettered medical attendance-just as the sick poor have in your noble charities depending on voluntary aid-that you have erected hospitals, built nursing homes, increased your hospital medical staff, and generally increased your first expenditure. Effectual medical aid for grave diseases car only be given under suitable conditions.

How does my paper apply? I will come to the heart of the question. Is it economical to supply trained nurses, give good food, increase the staff of medical men, and generally carry on your hospitals on the most improved principles? will try to answer this, briefly dwelling on a few principles of economy in relation to labour and the working classes.

We have in England, as they have in other countries, a large number called the proletariat-viz., those who give to the State only children and their work. Their economic condio tions are such that, provided work be found for them, they are able to live, saving something; but if sickness comes on, bringing with it loss of work and the expenses which sickness entails, this class is at once plunged into poverty. Disease does come, owing to the environment and nature of the work. The unskilled labourer who works in the open air is liable to pleurisy, pneumonia, bronchitis, rheumatism, heart-strain, and many other dizeases, whilst he is also liable to injury and to ulcers of the legs from collision with frag. ments of stone, wood, \&c. Now, neglect in many cases of sickness will convert a simple injury into a serious one, and acute disease into a chronic one, with a corresponding drain upon any revenues supplied by private beneficence or public charity.

Earjy help in sickness is invaluable. This does not merely consist in sending a medical man who gives a bottle of medicine; we now understand that medical relief comprises more than this. I do not undervalue medicine, but other things than medicine are wanted in every case of sickness. What are the requirements? Pure air, pure surroundings, food to baild up tissue, and, above all, intelligent application of medical principles which the nurse gives. The consequence is that

1 A paper read at a Conference of Yorkshire Guardians at Leeds on Nov. 12th, 1897. 
rander such conditions disease is cut short, the period of absence from work is lessened, and the expense of maintenance is diminished. I know this from experience. I have had this sconomic subject under my eye for the last five years, and I have no hesitation in saying that, at the Halifax Union Hospital, the period of sickness or detention in hospital has been materially cut short in all those diseases which are curable, and in that special class of diseases from which the outdoor worker suffers. Time will not allow me to dwell too long on this point, but I give you three classes of cases :1. Ulcers of the legs: You will find in all your union hospitals numbers of cases of ulcers of the legs which incapitate men from working. These men may remain in hospital for years, but under efficient nursing they are quickly cured. 2. Pulmonary affections: This class also gives us patients at all times of the year who are improved by treatment and discharged to sork again. 3. Cardiopaths: A large number come annually ander treatment who are much benefited.

The duration of stay in hospital will afford a valuable index as to the efficiency of your hospitals, and especially cases by our nurses. They are disappointed if the patient remains in a long time-it is a kind of personal reflection; and this is the spirit we desire to encourage in the interest of the patient and of the ratepayer.

Now another economical question comes in here. If you want your nurse to do her work efficiently it is necessary to provide for her suitable accommodation, good food, regular work but relieved from monotomy, and an annual holiday, for nursing work is exhausting. The food of the nurses may be economically managed, even though you do not adhere to a rigid dietary of " beef and mutton" varied by "mutton and beef."

I pass on to the question of hospital dieting. Your medical officer may very materially increase your annual expenditure, and hospital economics are well worth his consideration. Hospital dietaries vary; there is no uniformity; it may not be desirable. I think we do owe to the ratepayers and to our boards some regard to the expense. I believe we do recognise it. I submit to you two sets of diet tables-one from Halifax, the other from Cardiff:-

\section{I.-Diet Table, Str. Luke's Hospital, Halifax.}

Triomas M. Doxan, M.D., Medical Officer.

\begin{tabular}{|c|c|c|c|c|c|c|c|}
\hline Cost per week. & $\begin{array}{l}\text { No. } 1 . \\
2 s .3 d .\end{array}$ & $\begin{array}{l}\text { No. } 2 . \\
\text { 3s. } 5 \frac{3}{8} d .\end{array}$ & $\begin{array}{l}\text { No. } 3 . \\
18.11_{i 2}^{1} d .\end{array}$ & $\begin{array}{l}\text { No. } 4 . \\
2 s 5 d .\end{array}$ & $\begin{array}{l}\text { No. } 5 . \\
2 s . \\
2 s . \frac{1}{2} d . \\
2 s .3 .3 . \\
2 s . \\
2 \frac{1}{2} d .\end{array}$ & $\begin{array}{l}\text { No. } 6 . \\
\text { zs. } 9 \frac{2}{8} d .\end{array}$ & Remarks. \\
\hline Breakfast $\quad \ldots\}$ & $\begin{array}{l}6 \mathrm{oz} . \text { bread } \\
\frac{1}{2} \text { oz. butter } \\
1 \text { pint coffee }\end{array}$ & $\begin{array}{l}6 \mathrm{oz} . \text { bread } \\
\frac{1}{2} \mathrm{oz} . \text { butter } \\
1 \text { pint milk }\end{array}$ & $\begin{array}{l}6 \text { oz. bread } \\
\frac{1}{4} \text { oz. butter } \\
1 \text { pint coffee }\end{array}$ & $\begin{array}{l}6 \text { oz bread } \\
\frac{1}{2} \text { oz. butter } \\
1 \text { pint tea }\end{array}$ & $\begin{array}{l}6 \text { oz. bread } \\
\frac{1}{2} \text { oz. butter } \\
\frac{1}{2} \text { pint cocoa }\end{array}$ & $\begin{array}{l}6 \text { oz. bread } \\
\text { I pint milk }\end{array}$ & - \\
\hline Đinner $\quad \ldots \quad \ldots$ & $\begin{array}{l}3 \text { oz. meat } \\
4 \text { oz. rice } \\
2 \text { oz. bread } \\
4 \text { oz. potatoes }\end{array}$ & $\begin{array}{r}4 \text { oz. cooked } \\
\text { meat } \\
8 \text { oz. potatoes }\end{array}$ & $\begin{array}{l}8 \mathrm{oz} . \text { pudding } \\
\frac{1}{2} \text { pint beef-tea } \\
2 \mathrm{oz} . \text { bread }\end{array}$ & $\begin{array}{c}4 \mathrm{oz} . \text { cooked } \\
\text { meat } \\
8 \mathrm{oz} . \text { potatoes }\end{array}$ & $\begin{array}{l}8 \mathrm{oz} . \text { fish } \\
4 \mathrm{oz} . \text { bread or } \\
8 \mathrm{oz} . \text { potatoes } \\
4 \mathrm{oz} . \text { chop or } \\
2 \mathrm{eggs} \\
8 \mathrm{oz} . \text { rice } \\
\quad \text { pudding }\end{array}$ & $\begin{array}{l}4 \mathrm{oz} \text {. bread } \\
1 \text { pint beef-tea }\end{array}$ & $\begin{array}{l}\text { Green vegetables } \\
\text { occasionally } \\
\text { when in season. }\end{array}$ \\
\hline Tea & $\begin{array}{l}6 \text { oz. bread } \\
\frac{1}{2} \text { oz. butter } \\
1 \text { pint coffee }\end{array}$ & $\begin{array}{l}6 \text { oz. bread } \\
\frac{1}{2} \text { oz. butter } \\
1 \text { pint milk }\end{array}$ & $\begin{array}{l}4 \text { oz. bread } \\
\frac{1}{4} \text { oz. butter } \\
1 \text { pint tea }\end{array}$ & $\begin{array}{l}6 \text { oz. bread } \\
\frac{1}{2} \text { oz. butter } \\
1 \text { pint tea }\end{array}$ & $\begin{array}{l}6 \text { oz. bread } \\
\frac{1}{2} \text { oz. butter } \\
\frac{2}{2} \text { pint tea }\end{array}$ & $\begin{array}{l}6 \mathrm{oz} . \text { bread } \\
1 \text { pint milk }\end{array}$ & - \\
\hline
\end{tabular}

II.-Diet Table, Cardiff Union Hospital.

AlFred SheEx, M.D., Medical Officer.

\begin{tabular}{|c|c|c|c|c|c|c|c|}
\hline Cost per week. & $\begin{array}{l}\text { No. } 2 . \\
2 s .9 d .\end{array}$ & $\begin{array}{l}\text { No. } 3 . \\
2 s .7 \frac{1}{2} d .\end{array}$ & $\begin{array}{l}\text { No. } 4 . \\
2 s .2 d .\end{array}$ & $\begin{array}{l}\text { No. } 5 . \\
2 s .5 d .\end{array}$ & No. 6. & $\begin{array}{c}\text { No. } 7 . \\
2 s .\end{array}$ & Remarks. \\
\hline $\begin{array}{r}\text { Breakfast, } \\
8 \Delta . M .\end{array}$ & $\begin{array}{l}6 \text { oz. bread } \\
\frac{1}{2} \text { oz. butter } \\
1 \text { pint tea }\end{array}$ & $\begin{array}{l}8 \mathrm{oz} . \text { bread } \\
\frac{1}{2} \text { pint milk }\end{array}$ & - & $\begin{array}{l}4 \text { oz. bread } \\
\frac{1}{2} \text { oz. butter } \\
\frac{1}{2} \text { pint cocoa }\end{array}$ & $\begin{array}{l}6 \text { oz. bread } \\
\frac{1}{2} \text { oz. butter } \\
1 \text { pint tea }\end{array}$ & $\begin{array}{l}6 \text { oz bread } \\
1 \text { pint gruel } \\
\frac{1}{4} \text { pint milk }\end{array}$ & - \\
\hline $\begin{array}{ccc}\text { Dinner, } & 12.30 \\
\text { P.M. } & \ldots & \cdots\end{array}$ & $\begin{array}{c}6 \text { dajs. } \\
4 \text { oz. cooked } \\
\text { meat } \\
12 \text { oz. potatoes } \\
\text { Tuesday. } \\
\frac{1}{2} \text { pint pea soup } \\
4 \text { oz. bread }\end{array}$ & $\begin{array}{l}2 \text { oz. bread } \\
1 \text { pint beef-tea }\end{array}$ & $\begin{array}{c}\text { Daily. } \\
8 \mathrm{oz} \text { bread } \\
2 \frac{1}{8} \text { pints milk }\end{array}$ & $\begin{array}{l}3 \mathrm{oz} . \text { cooked } \\
\text { meat } \\
8 \mathrm{oz} . \text { potatoes }\end{array}$ & $\begin{array}{l}8 \mathrm{oz} . \text { potatoes } \\
6 \mathrm{oz} . \text { fish or } \\
8 \mathrm{oz} . \text { potatjes } \\
4 \mathrm{oz} . \text { chop } \\
4 \mathrm{oz} . \text { bread or } \\
2 \text { eggs } \\
\text { rice pudding }\end{array}$ & $\begin{array}{l}\text { Same as house } \\
\text { diet }\end{array}$ & 一 \\
\hline supper, 6 P.M. & $\begin{array}{l}6 \text { oz. bread } \\
\frac{1}{2} \text { oz butter } \\
1 \text { pint tea }\end{array}$ & $\begin{array}{l}3 \mathrm{oz} \text {. bread } \\
1 \text { pint milk } \\
\text { porridge }\end{array}$ & - & $\begin{array}{l}1 \text { pint milk } \\
\text { porridge } \\
4 \text { oz. bread }\end{array}$ & $\begin{array}{l}6 \mathrm{oz} . \text { bread } \\
\frac{1}{2} \text { oz. butter } \\
1 \text { pint tea }\end{array}$ & - & - \\
\hline
\end{tabular}

* Cost with beef-tea, 3s. 9d.; with chop, 2s. 10d.; fish, 3s.; eggs, $2 s .8 d$.

if you confine your observations to acute diseases. The chronic cases are also much ameliorated by efficient nursing and liberal dietary, and a large number are sent out recruited for summer, spring, autumn ; probably some come in again anring the winter months. The trained nurse will not allow "loafers," of whom there are so many to be found in union hospitals. She is anxious to get her patients well, and nothing can equal the painstaking work done at St. Luke's Hospital, Halifax, in regard to acute disease and surgical
I have estimated, as you see, the cost of these dietaries per week, and one cannot go very far wrong with those dietaries which are made by me the basis of food-treatment.

The sick are placed on one of these scales, but this has to be supplemented and varied, and does not adequately represent all the cost per week. Herein comes waste. The patient is by right entitled to some form of diet, representing so much bread, so much meat, so many potatoes, so much milk, which is drawn each day whether the patient can eat 
it or not. Here there is room for reform, but I am not prepared with a definite scheme. We have recognised it, and our superintendent, has tried to grapple with it in one or two ways. Extra bread is given to those who can eat it between meals from what is left, but it is made more appetising by a little jam or marmalade Meat left over is made into little hashes, whilst spare potatoes are always used in some little dish. You know from your experience of your union hospitals that the sick cannot eat each day the diet on their bed-cards, but you must have a diet scale, and this must be drawn daily, otherwise the patient will complain. 'This is one part of Poor-law economics upon which collective wisdom may throw a.light.

The dietetic question presents another aspect in reference to the use of stimulants. My rule is the same that I employ with my private patients. I order stimulants, but not in a routine way. Beer is rarely given, never pro formâ. Other stimulants are given in medicinal doses, in ounces-so many tablespoonfuls so many times a day. I bave fully considered this question in all its bearings. I admit that there are many who are brought to the union hospital through drink and improvidence therefrom, bat they do not amount to 18 per cent. My statistics on this point agree with those of one of the greatest observers of the habits of the very poor-viz, Mr. Charles Booth-who, inquiring into the condition of 4000 of the submerged, found that of those reduced to poverty 4 per cent. were loafers, 14 per cent. were addicted to drink, 27 per cent. were poor through illness or had , been the victims of misfortune, and 55 per cent. were thrown out of employment. So that this reason cannot be legitimately urged-viz, that for the benefit of the 18 per cent. we should penalise the 82 per cent. whose illness may be due to legitimate causes. I admit that the medical officer should exercise vigilance over the use of stimalants, but his hands should not be absolutely tied.

Before passing from the environment of the hospital, where nowadays the sick poor are humanely treated, where dietaries and nursing are ample and where medical aid is of the most effective kind, I might add one or two words on the humanising influence of the nurses, on the healthy influence they exercise on their patients-influences which bave to my knowledge extended in many cases outside the hospital walls, leading to a return to better ways on the part of many men and women. We cannot measure in money weight human sympathy or the kindness or devotion to work on the part of the nurses, but yet I venture to say it has to be reckoned with as a great economic force. I also cannot but think that the personal visits of the guardian who disinterestedly and kindly interests himself in hospital work, visiting the wards, encouraging all by his words, lifting the fallen, reproving maybe, but sympathising with deserving objects of charity, must also have a high economic value.

The sick poor who are admitted to the modern union hospital are more fortunate than those who remain outside in their own homes, and my final words will be briefly devoted to outdoor medical relief. The same principles are applicable. Effectual aid is equally desirable. Is it available? You have a large staff of medical officers who are engaged to attend the ontdoor poor at their own homes, to give not only first aid, but to attend in prolonged and serious cases of illuess. If we look at the economical conditions of this staff we shall find that the principle of economy is very manifest. Medical officers are appointed who have large, sometimes enormous, districts, who find their own medicines and appliances, and who are paid at such a scale that each visit is remunerated at a very low rate.

The old argument is used. The law of supply and demand comes in. If guardians can obtain medical men at such a price, why should they pay more? 'The answer is not for me to give; but I am anxious to direct your attention to some aspects of these appointments. Efficient aid is what is wanted. Neglect may convert a common cold into a serious illness. The medical officer who is called in ought, in order to complete his work, to be able to prescribe for his patient and also to order any necessary food. It appears to me that it must hamper the medical officer to find all necessaries out of his salary, and certainly as he deals with disease in the most unfavourable surroundings he requires other help. His medicine alone can do very little good unless supplemented by nursing in the houses of the poor. The ouddoor Poor-law nurse seems to me a fitting complement to perfect the system. This nurse should visit all cases attended by the Poor-law medical officer, and give force to all the medical directions. She should supervise all removals to hospital, and she should assist in many other wayś. I am not in favour of increasing the work of the outdoor medical officer by this-viz., by keeping cases out of the hospita? under his care. No, I think that it is better to send into the hospitals all cases that require prolonged or careful nursing and good food. I very much regret to note that there is such repugnance to the workhouse hospitals, that patients remain out as long as they can, often without medical aid, and sometimes only enter to die, swelling the death.rate in our hospitals. The guardians also know that a number of patients are sent in who are approaching their end. It is difficult to know how to deal with this class of cases. In many instances it would be more economical to increase the outdoor relief for the few days such patients may live besides being more humane. With outdoor nurses this would be possible. We cannot disguise from ourselves that there is, too, a repugnance to apply to the parochial medical officer. This feeling is laudable, but is a reflection on the system which ought not to exist at the present day when guardians are hamanising their work. I do not want you to break down the barriers or to make it any easier to obtain free medical advice. No, but I do want to convince you that you ought not to give simply cheap medical advice; that as you are entrusted by the State with the relief of suffering amongst the poor, you should give effectual medical aid, anci and that you cannot give effective aid without the best machinery.

Gentlemen, in conclusion I can only repeat that I am not a doctrinaire. I give you my views and suggestions for what they are wortb. It needs great care in administering your Poor-law funds, avoiding parsimony as well as extravagance. There never was a time when the needs of the deserving poor were more carefully considered and relieved, and there is no country like England where the sick poor are so tenderly and devotedly nursed. Medical advice in sickness is the great question of the day agitating the philanthropists from one end of England to the other. All kinds of schemes have been formulated to grapple with sickness amongst the labouring poor; but I hold that with an efficiently organised Poor-law system no poor person should dread the approach of sickness, and that for medical aid in sickness there should be no stigma in accepting such aid from the Poor.law. Halifax

\section{PUERPERAL SEPTICAMMA TREATED WITHOUT STREPTOCOCCIC SERUM ; RECOVERY.}

\section{BX EUSTACE M. SWANWICK, L.R.C.P. LOND., M.R.C.S. ENG., \\ PHYSICLAN TO HARTLEPOOLS HOSPITAX,}

THE above title is used to compare the case with the very full and interesting account of a case of puerperal septicæmia given by Dr. Rawlings in THE LAArCET of Aug. 7th last. As in Dr. Rawlings's case, so in mine, there is no account to offer in the way of bacteriological examination.

A primipara, aged twenty-three years, whom I was engaged to attend at the end of July, sent for me on themorning of July 14th, 1897. The labour began about 1 A ir The head presenting in the third cranial position made the labour slightly less normal than otherwise it might have been. A small quantity of a mixture of chloroform and rectified spirit relieved the urgency of the pain and the child was born at 5.25 A.M. There was a slight perineal tear, hardly to be dignified by the rame of rupture, as it did not seem to involve any muscle. Before each infrequent examination my hands were rinsed in a 1 in 1000 solution of perchloride of mercury and lubricated with carbolised vaseline. On completion of the third stage a soluble pessary containing ten grains of iodoform was passed bigh up into the vagina, a binder applied, and the patient was left feeling comfortable. About 10 A.M. the temperature was $99^{\circ} \mathrm{F}$. and the pulse was 84 ; there was no pain or malaise. In the evening the urine was drawn off with a catheter, well washed in disinfectant. Doring the 15th the patient seemed to be going on well. On the 16 th, at 12.30 P.M., the temperature was $1008^{\circ}$; at 2.30 P M. there were pains all over the head, back, and limbs, and a feeling of cold water down the back, but no fnll rigor; the- 